\title{
THE EFFECT OF GOVERNMENT BONDS, INFLATION, AND EXCHANGE RATE IN ACHIEVING SDGS
}

\author{
Muhammad Rafi Bakri ${ }^{1}$ \\ Politeknik Keuangan Negara STAN \\ 1302180086_rafi@pknstan.ac.id \\ Anastasya Utami \\ Politeknik Keuangan Negara STAN \\ 1302180636_anastasya@pknstan.ac.id
}

\begin{abstract}
This study aims to examine the effect of bonds, inflation rates, and exchange rates on economic growth to achieve Indonesia's 2030 sustainable development goals, namely reducing government and poverty. This study uses a quantitative regression analysis method with a path analysis approach to determine the direct or indirect effect between variables. The variables used are published values, inflation, exchange rates, economic growth, poverty rates, and poverty in Indonesia in 2016-2020. Based on the path analysis, the coefficient of determination of $60.72 \%$ indicates that the diversity of the data of $60.72 \%$ can be explained in the model. Government Bonds have a direct and significant effect on the economic growth of -1,243. Government obligations indirectly affect the level of movement and mission of 1,098 and 1,128, respectively. The inflation rate directly affects the rate of economic growth of 0.712 . The inflation rate has no direct effect on the movement level and poverty of -0.6294 and -0.6644. The exchange rate has no significant direct or indirect effect on economic growth, movement, and poverty. This study concludes that the government needs to control inflation and inflation so that the economy can be achieved and reduce inflation and poverty.
\end{abstract}

Keywords: Government Bond, Inflation Rate, Exchange Rate, Economic Growth, SDG's

\begin{abstract}
ABSTRAK
Penelitian ini bertujuan untuk mengkaji pengaruh obligasi pemerintah, tingkat inflasi, dan nilai tukar terhadap pertumbuhan ekonomi untuk mencapai tujuan pembangunan berkelanjutan Indonesia 2030 yaitu mengurangi pengangguran dan kemiskinan. Penelitian ini menggunakan metode analisis regresi kuantitatif dengan pendekatan analisis jalur untuk mengetahui pengaruh langsung atau tidak langsung antar variabel. Variabel yang digunakan adalah nilai obligasi yang diterbitkan pemerintah, inflasi, nilai tukar, pertumbuhan ekonomi, tingkat pengangguran, dan kemiskinan di Indonesia tahun 2016-2020. Berdasarkan analisis jalur, nilai koefisien determinan sebesar 60,72\% menunjukkan bahwa keragaman data sebesar $60,72 \%$ dapat dijelaskan dalam model. Obligasi Pemerintah berpengaruh langsung dan signifikan terhadap pertumbuhan ekonomi sebesar -1.243. Obligasi pemerintah memiliki pengaruh tidak langsung terhadap tingkat pengangguran dan kemiskinan sebesar 1,098 dan 1,128. Tingkat inflasi berpengaruh langsung terhadap laju pertumbuhan ekonomi sebesar 0,712. Tingkat inflasi berpengaruh tidak langsung terhadap tingkat pengangguran dan kemiskinan sebesar -0,6294 dan -0,6644. Nilai tukar tidak berpengaruh signifikan baik secara langsung maupun tidak langsung terhadap pertumbuhan ekonomi, pengangguran, dan kemiskinan. Kesimpulan dari penelitian ini adalah pemerintah perlu mengendalikan obligasi pemerintah dan inflasi agar pertumbuhan perekonomian dapat tercapai serta dapat menurunkan tingkat pengangguran dan kemiskinan. Kata Kunci: Obligasi Pemerintah, Inflasi, Nilai Tukar, SDG
\end{abstract}

Klasifikasi JEL: C300 


\section{INTRODUCTION}

\subsection{Background}

The Sustainable Development Goals (SDGs) hope for the entire world community to be free from unfavourable living conditions. Currently, various adverse conditions can still be found, such as poverty, hunger, and war. UNDP fully supports the SDGs internationally and regionally to be free from these seventeen goals in the next fifteen years (UNDP, 2015). One of the dire conditions that Indonesia is still experiencing is poverty and unemployment. Poverty is a multidimensional condition because it relates to various sectors on an ongoing basis. This makes poverty a complex problem (Ferezagia, 2018). Based on calculations from the IMF World Economic Outlook October 2020 and World Bank Povcal data, the current poverty rate due to the Covid-19 pandemic and the future is as follows.

Figure 1. Projection of the World

Poverty Level for 2019-2030

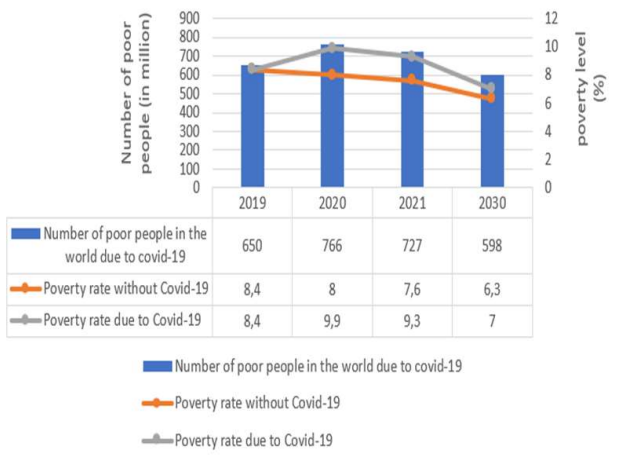

Source: brookings.edu

The table above shows the change in the trendline of the poverty rate. The Covid-19 pandemic has a long-term effect on the poverty rate, increasing compared to projections in normal conditions without Covid-19. In Indonesia, as reported by Katadata, the number of poor people until the end of
2020 increased by $5.09 \%$ compared to the previous year due to deviations in poverty projections due to Covid-19. Reporting to Global Finance Magazine, Indonesia is ranked 94th in 2020 as the poorest country in Indonesia's Poverty Conditions. Compared to neighbouring countries, Indonesia is only superior to Timor Leste and Papua New Guinea. Indonesia lags behind Malaysia, especially Brunei and Singapore. Seeing these conditions, poverty alleviation is the most critical development priority for Indonesia as a developing country (Mansi, 2020).

On the other hand, unemployment has a significant impact on the dynamics of people's lives, not only per individual. The majority of a country's economic problems stem from the country's unemployment rate (Khuhawar, 2019). The International Labor Organization (ILO) states that the unemployment rate of the world community from 2011 to 2020 is as follows.

Figure 2. World Unemployment Rate 2011-2020

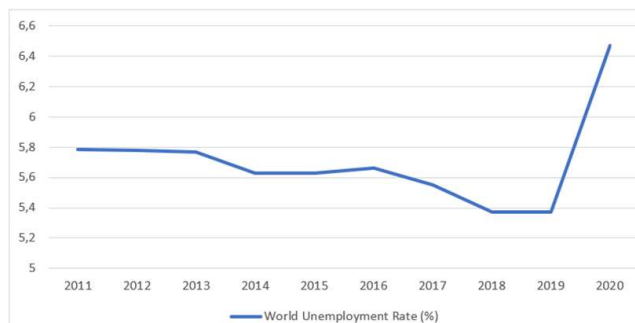

Source: World Bank

The table above shows the change in the trendline of the unemployment rate. From 2011 to 2019, the world unemployment rate experienced a gradual downtrend. However, in 2020, Covid-19 caused the unemployment rate to reach a record high of $6.471 \%$, beating 2003's 6.201\%. The Central Statistics Agency (BPS) stated that the open unemployment rate (TPT) in Indonesia as of August 2020 was $7.07 \%$. This figure is up 1.84 
percentage points compared to August 2019 as a result of Covid-19. The majority of unemployment comes from layoffs (PHK) in the micro-business sector (Indayani \& Hartono, 2020).

Poverty and unemployment are two of the seventeen SDGs: point 1 on eradicating poverty and point eight on employment and economic growth. Seeing the success achieved in 2015, where the UN was able to reduce the number of the world's poor by $50 \%$, the United Nations Development Program (UNDP) believes that by 2030, poverty alleviation can be eradicated worldwide. The UNDP poverty threshold is below, living on less than $\$ 1.25$ per day. There are still 800 million people worldwide living below this figure, which is the extreme poverty level in Europe. To improve the standard of living, one of the most important factors is that everyone must have a job that has sufficient wages to support himself and his family. The current situation is that job growth (Demand) is not keeping pace with the growth of the labour force (Supply) in the labour market (UNDP, 2015). A labour market is a meeting place for sellers and buyers of labour. The labour force that does not have a job is the seller of labour in this market, while the job providers or those who need workers are the buyers. Synergic conditions between sellers and buyers can be created through good cooperation between all relevant parties, namely labour sellers, labour buyers, and the government (Gatiningsih, 2017). To achieve this balance, UNDP has included work as part of the SDGs (UNDP, 2015).

The economic growth of a country describes the country's inflation rate. Inflation can have a domino effect that harms Indonesia's economic growth (Ardiansyah, 2017). To support economic growth, the exchange rate can play a significant role in controlling inflation.
The costs \& benefits of exchange rate policies need to be carefully considered to maintain market price stability (Fetai, 2016). Economic growth was also influenced by the fiscal deficit in the previous period, taking into account the effect of the lag variable (Swasono, 2015). DJPPR said that to cover the deficit, the government issued government bonds (SUN) as a source of financing receipts from Government Securities (SBN). SUN is divided into two types, namely State Treasury Letters (SPN) and State Bonds (ON). SPN is known as T-Bills (DJPPR, 2015).

Poverty and unemployment are twin problems that affect the economic condition (Muhammad, 2019). A recent study conducted by Berardi \& Marzo (2017) shows that economic growth does not directly impact poverty. However, a decrease in the unemployment rate can directly impact poverty (Purnomo, 2019). The decline has a relationship with economic growth. Through Okun's Law, the unemployment rate can be reduced by $1 \%$ if a country's GDP grows by around $4 \%$. It is interesting to see the large portion of government bonds as a source of financing receipts and inflation rates and exchange rates in influencing poverty and unemployment rates in Indonesia through economic growth.

In conducting this research, there are several previous studies related to the title appointed by the author. The first study entitled "Poverty Reduction and Sustainable Development in Nigeria" was conducted by Chinedu S. Udeh and Kemal Ozden in 2018. The research shows that sustainable development is impossible without effective poverty alleviation, using research sites in Nigeria. The research method used is a literature study. The Nigerian government issued several programs to alleviate poverty, such as OFN, People's 
Bank, and NEEDS. Unfortunately, poverty alleviation is accompanied by the implementation of programs that are not appropriately managed. This can result in not achieving sustainable development and security.

The following study entitled "The Effect of Economic Growth concerning Unemployment" was conducted by Shkumbin Misini in 2017. The study explains that economic growth has little effect on poverty alleviation and unemployment. By taking the background in Kosovo, the research was conducted using descriptive statistics. Economic growth there could not raise the standard of living of the people. The difficulty of finding employment opportunities exacerbates this. This makes poverty alleviation unaffected by economic growth, plus the condition of the unemployed who are already poor.

Fifi Nur Hidayah conducted the third research in 2020. The research entitled "The Effect of Foreign Debt, Rupiah Exchange Rate and Government Bonds on Indonesia's Economic Growth" focused on the object of Bank Indonesia's research during the period 2010 to 2019. The study showed that the issuance of government bonds, partially, does not affect Indonesia's economic growth. The research method used is a quantitative method using regression analysis. To influence economic growth, it is necessary to have the right strategy in capital formation. Although partially unable to affect economic growth, government bonds and foreign debt and the exchange rate can simultaneously affect Indonesia's economic growth.

The last research entitled "Analysis of the Effect of Inflation, Interest Rates, and Exchange Rates on Gross Domestic Product (GDP) in Indonesia" was conducted by Hatane Samuel and Stephanie Nurina in 2014.
This study shows that inflation and exchange rates have a significant positive impact on economic growth. The method used in this study is a quantitative method using Path Analysis. The inflation rate can be an excellent mediator to be able to link interest rates with economic growth. If the interest rate stands alone, there is no significant relationship with the exchange rate on economic growth.

The purpose of this study is to see whether in Indonesia there is a relationship between 1) government bonds on Indonesia's economic growth; 2) inflation rate on Indonesia's economic growth; 3) the exchange rate of the Rupiah against the United States Dollar against Indonesia's economic growth; 4) Indonesia's economic growth on the unemployment rate in Indonesia; 5) Indonesia's economic growth against the poverty rate in Indonesia; 6) government bonds indirectly to the unemployment rate in Indonesia; 7) Inflation rate indirectly to the unemployment rate in Indonesia; 8) the exchange rate of the Rupiah against the United States Dollar indirectly affects the unemployment rate in Indonesia; 9) government bonds indirectly to the poverty rate in Indonesia; 10) inflation rate indirectly to poverty rate in Indonesia; and 11) the exchange rate of the Rupiah against the United States Dollar indirectly affects the poverty rate in Indonesia.

\subsection{Literature Reviews}

\subsubsection{Sovereign Debt Instruments}

Sovereign Debt Instruments can be defined as securities issued by the government in a country in the form of debt acknowledgement in which the government will make payments of interest and principal debts made by the state for a certain period (Sari, 2020). Based on Law No. 24 of 2002, SUN is 
defined as acknowledging debt in rupiah and foreign currencies whose principal and the state guarantees loans. Types of government bonds can be categorized into four types: state treasury bonds, retail bonds, government bonds, and retail saving bonds. The purpose of issuing government bonds is to cover the state's financial deficit, generate cash in the short term and manage the country's portfolio.

The Directorate General of Financing and Risk Management (DJPPR) is responsible for managing the issuance of sovereign debt securities. DJPPR, as the agency with the right to carry out management related to financing, has several functions, namely carrying out planning related to issuance to managing state debt securities, developing the market share of government securities, and providing publications to the public. So that structured management will provide benefits related to the issuance of government bonds, including as a fiscal instrument, investment medium, and financial market instrument.

\subsubsection{Poverty}

Poverty is a condition in which an individual cannot obtain adequate primary needs to sustain his life (Deonandan, 2019). Another definition, according to the Central Bureau of Statistics, explains that poverty is the inability of individuals to meet their needs, both food and non-food. Poverty is a common problem encountered in developing countries so that the loyal government of a country will try to provide a decent life for its people. Poverty will also harm social life if left unchecked because it will lead to crime.

Poverty is not a static event in a country. A person's needs can sometimes go up and down according to one's abilities so that poverty can hit a person within a certain period or for a more extended period (Goulden, 2014). In helping alleviate poverty for the population, the government takes various ways to provide employment opportunities, providing business training to increase one's values and abilities. So that in overcoming and knowing the level of poverty in a country requires accurate data.

Factors causing poverty in several opinions can be described as follows: firstly, the low level of education obtained, causing the ability to think and get a decent job to be reduced, secondly, the low level of health obtained, the state has a function in supporting and being a driver in protecting public health if conditions are met. If health is not fulfilled correctly, the potential for malnutrition and thinking power will be hampered, and thirdly, the limited number of job opportunities has resulted in the number of job seekers being more than the number of jobs. So that by referring to these conditions will give birth to poor people, poor people can be interpreted as people whose total expenditure is below the poverty line. Therefore, poverty alleviation must be carried out by the government by providing incentives in the form of providing facilities and infrastructure and assistance in the form of providing skills and opening up employment opportunities in a country, which is an essential focus of every government.

\subsubsection{Inflation}

Inflation is an event where there is an increase in the price of an item in a country that runs continuously caused by market mechanisms caused by certain factors (Yunita, 2018). According to Chi Wei Su (2020), inflation can be caused by export receipts in a country that are 
considered inelastic and the country's economic problems. Continuous inflation in a country will have a significant impact, increasing the cost of living, which will lead to poverty. Inflation can be categorized into 3, namely demandpull inflation, cost pull inflation, bottleneck inflation.

Inflation is influenced by the amount of money circulating in a country and the amount of production and demand made by the community, causing the rise and fall of the price of goods or services (Coibion, 2019). The inflation rate will also affect the interest rates applied by the central bank of a country. If there are inflationary conditions in a country, it will increase the interest rates set for banks that impact changes in goods prices and the economic growth of society and global. So that government decisions through the central bank are indispensable in regulating a country's inflation rate through monetary policy (Sama, 2018).

The indicator used to measure a country's inflation rate is the Consumer Price Index (CPI). Changes in the CPI over a certain period can indicate consumer goods in society (Indiarti, 2018). The CPI is used in a survey to determine the cost of living in a country, which will be monitored by the Central Statistics Agency, which will then be monitored for a certain period to determine the impact of changes in the $\mathrm{CPI}$ in a country.

\subsubsection{Exchange Rate}

The exchange rate is defined as comparing value, price, or currency compared to other types of currency or exchange rates (Wijaya, 2017). A country has its exchange rate, which is used to determine its country's currency with the currencies of other countries. The exchange rate of another country, known as foreign exchange, is influenced by the demand and supply of foreign currency. Foreign exchange rates are needed to conduct transactions with other countries. Therefore, a country is obliged to maintain the value of its currency in order to be able to avoid the risks posed in the export and import markets (Engel, 2013).

Changes in the exchange rate in a country are the factors responsible for changes in a country's exports and imports (Nguyen, 2020). Lowering the exchange rate of a country's currency will affect increasing the cost of importing raw materials and equipment that will be used in assisting the process of providing goods and services in a country, while on the other hand, a decrease in the value of the currency will affect the value of a country's exports. So it can be concluded that changes in the exchange rate will impact the country's economy.

According to Sukirno (2003), several factors affect the exchange rate on the rupiah exchange rate, namely the first changes in people's tastes or abilities, second changes related to exported goods, the inflation rate of a country, changes in interest rates determined by the central bank and economic growth. A country. Therefore, referring to the data, changes in exchange rates can affect the price changes associated with a product to be higher than before (Ginting, 2013). So, looking at the exchange rate's movement can provide mitigation in the implementation of exports in a country.

\subsubsection{Unemployment}

Unemployment is a condition where a person has entered working age, is looking for work, and can work but does not yet have a job for some reason (Mpofu, 2020). Meanwhile, according to the Central Bureau of Statistics, unemployment can be interpreted as a condition where people who do not have 
a job but are in the process of looking for work, want to create a job or are not looking for work because they have got a job but have not done the job. Unemployment can cause several problems in the economy, including reducing economic output, decreasing people's purchasing power, and increasing poverty (Falk, 2021).

In theory, unemployment can be caused by many factors. For example, in a company with a large enough cost to produce an item, management decisions can reduce employees, causing unemployment. Meanwhile, according to Okun's law, unemployment can impact a country's economy, where unemployment has a negative relationship with a country's economic growth because, with much unemployment, it will increase the burden on the state that must be financed (Basmar, 2020). Therefore, unemployment is a problem for an individual and a problem within a country that the state must resolve in reducing the level of social inequality.

$$
\text { In various sources, }
$$
unemployment is an option in completing a country's economy because it is related to inflation. If a country chooses to reduce the unemployment rate, the inflation rate will likely increase and vice versa (Perazzi, 2017). An increase in the number of unemployed in a country will increase the number of poor social groups, which, if not addressed, will have a crime impact on the surrounding community due to not being able to meet their needs. So it can be concluded that each country must pay attention to the impact that occurs to maintain stability between unemployment and the inflation rate by the policies drawn up.

\subsubsection{Economic Growth}

Economic growth is a process related to increasing economic indicators related to the size of the national economy, gross income per capita, and macroeconomic indications in a country (Haller, 2012). Economic growth can also be related to how a country uses available resources to meet the production capacity. The results of a country's production compared to a specific period will be known as GDP. GDP is the quantity of production of a good or service produced by a country in a certain period and is usually used as a benchmark for the development of a country (Costanza, 2014).

GDP is the most frequently used indicator to determine the economic development of one country with another, which is converted into foreign currency (Gourinchas, 2013). Basically, in finding the value of a country's GDP, an equation can be used, namely by adding up household consumption, government spending, import value, and export value in a country. So that through the use of GDP, a country can find out economic resources, economic growth, and business development opportunities (Sessu, 2018).

GDP, in theory, can be described if the position of expenditure is the same as the amount of income that a country gets, but because in practice, it is difficult to do so, the approach taken is usually an expenditure approach (Rosa, 2019). One of the variables used in determining macroeconomic policies in a country will be influenced by several factors, namely inflation, interest rates, and exchange rates. So that the policies carried out by the government in a country should be carried out wisely because every decision-making related to GDP will affect other variables or factors in its implementation. 


\section{RESEARCH METHOD}

This study is designed to determine the effect of government bonds, inflation rates, and exchange rates on economic growth, unemployment rates, and poverty levels in Indonesia, either directly or indirectly, to achieve Sustainable Growth Development (SDG) in 2030. The study was conducted using the method of path analysis.

The data used in this study is quantitative data in the form of units of account. The data consists of the number of outstanding government bonds, Indonesia's inflation rate, the rupiah's exchange rate against the United States dollar, the rate of economic growth, and the unemployment rate. The data used is in the 2016-2020 periods. The data is secondary data obtained from various related sources using the literature study and documentation method.

The data analysis technique used in this research is path analysis. This technique extends multiple linear regression analysis to find a causal relationship between the independent variables and the dependent variable. In path analysis, a variable has a dual role, namely as an independent variable in one path but becomes a dependent variable in another path. Path analysis can also calculate the direct or indirect effect of an independent variable on the dependent variable.

Before processing the data using a regression test, the research data must be tested for normality first. The output of the normality test is a visual image showing the distribution of the data using histogram graphs and scatterplots (Sari, 2020). By observing the histogram graph, the data is normally distributed if the graph is in the form of a bell. Using a scatter plot, the data will generally be distributed if the points spread around the diagonal line and do not accumulate on one side of the diagonal line.

The multicollinearity test aims to test whether the regression model correlates with independent variables (Allam, 2020). A good multiple regression equation is an equation that is free from multicollinearity between the independent variables. In deciding the regression model, there are symptoms of multicollinearity, or the tolerance value and VIF (Variance Inflation Factor) cannot be used. The general value used as a reference is the tolerance value $>0.1$. When the tolerance value is more than 0.1 , the regression model can be ascertained to be free from multicollinearity symptoms. The study is free from multicollinearity if the VIF value is $<10$.

The heteroscedasticity test is used to determine whether or not there is a classical assumption of heteroscedasticity, namely the variance inequality of the residuals for all observations in the regression model (Chen and Zhang, 2020). The prerequisite that must be met in the regression model is the absence of heteroscedasticity symptoms.

Path analysis is an extension of multiple linear regression analysis, or path analysis is the use of regression analysis to estimate causality relationships between variables that have been previously determined based on theory $(\mathrm{Li}, 2018)$. Path analysis is used to analyze the relationships between variables to know the direct or indirect effect of a set of independent variables (exogenous) on the dependent variable (endogenous). The benefit of path analysis is to explain the phenomenon being studied or the problem under study, namely the determination of which independent variables have the dominant influence on the dependent variable and 
explore the mechanism of the influence of the independent variable on the dependent variable. The intervening variable is an intermediate or mediating variable. Its function is to mediate between the independent variable and the dependent variable. To test the effect of the intervening variable, the path analysis method was used. Path analysis is an extension of multiple linear regression analysis, or path analysis is used to analyze the pattern of relationships between variables to know the direct or indirect effect of a set of independent variables (exogenous) on the dependent variable (endogenous). The path coefficient is a standardized regression coefficient (standardized regression coefficient).

The research model in conducting path analysis in this study is as follows.

Figure 3. Path Analysis

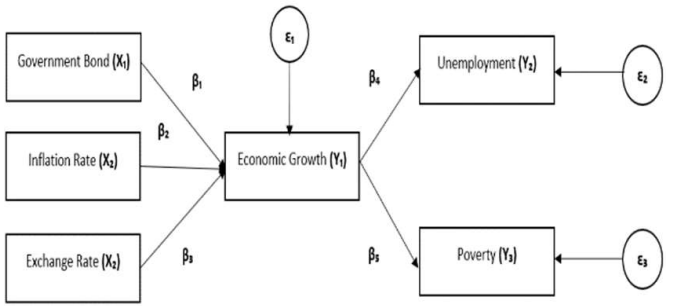

Source: Processed Data

$\mathrm{Y}_{1}=\beta_{1} \mathrm{X}_{1}+\beta_{2} \mathrm{X}_{2}+\beta_{2} \mathrm{X}_{3}+\varepsilon_{1} \ldots \ldots$ (1)

$\mathrm{Y}_{2}=\beta_{4} \mathrm{Y}_{1}+\varepsilon$

$\mathrm{Y}_{2}=\beta_{5} \mathrm{Y}_{1}+\varepsilon_{3}$

\section{RESULTS AND DISCUSSIONS}

\subsection{Normality Test}

Based on Figure 4, there is a histogram graph that visualizes the level of normality of the variables in the study. The histogram graph shows a bell shape which indicates the data in the study are normally distributed.
Figure 4. Normality Test-Histogram
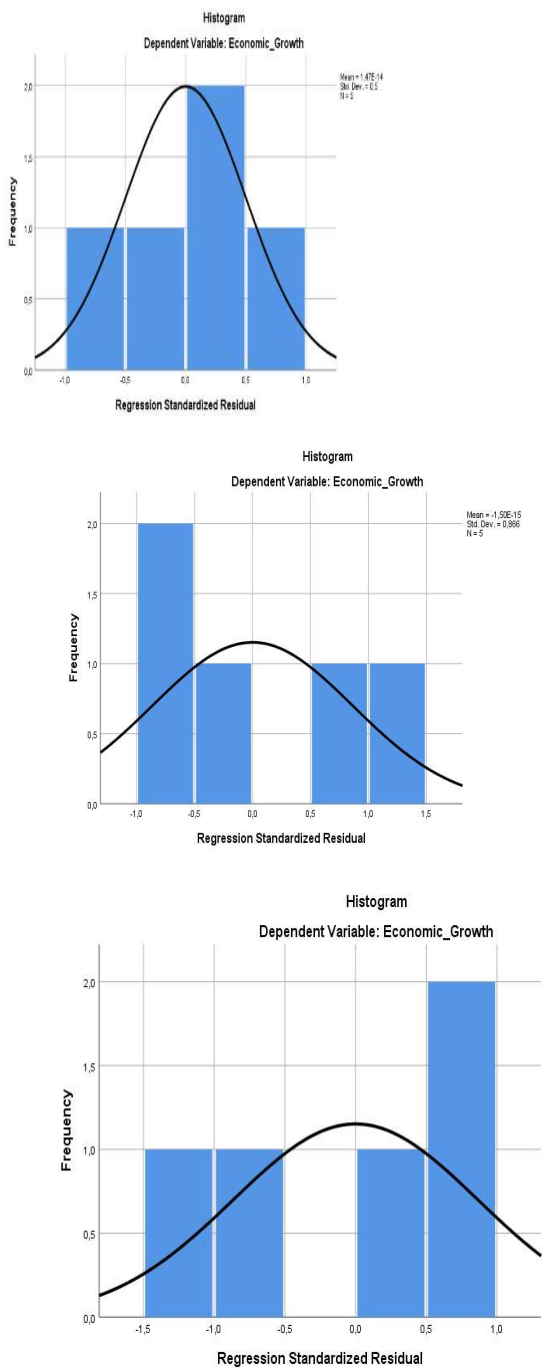

Source: Processed Data

In order to anticipate errors in visualizing the histogram graph, the researcher added one more normality test, namely the p-plot normality test. Based on the p-plot graph in Figure 5, the data is spread evenly and does not form a specific pattern so that the data is normally distributed.

Figure 5. Normality Test-P-Plot 

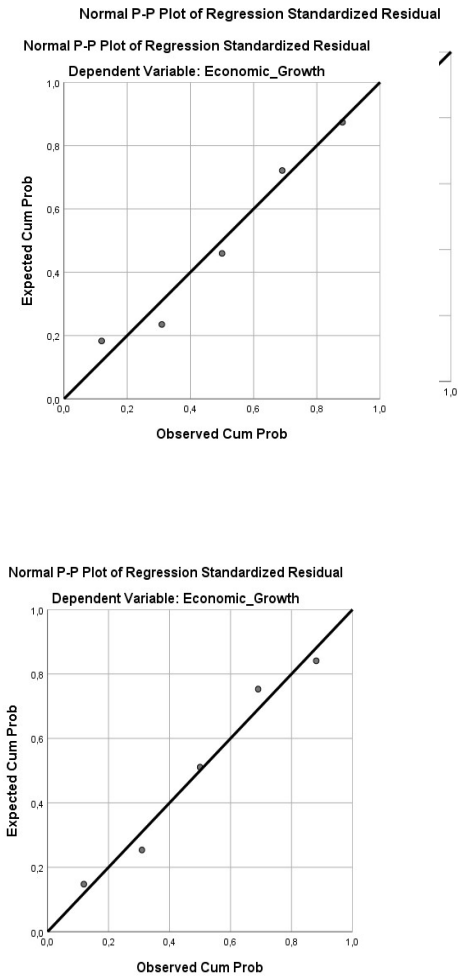

Source: Processed Data

\subsection{Heteroscedasticity Test}

Based on the glejser test, as shown in Figure 6, a scatter plot graph is obtained, which shows the data is randomly distributed and does not form a specific pattern. Figure 6 also shows that the data distribution is around zero points so that this research model is free from heteroscedasticity problems. In other words, the variables in this study are homoscedasticity.

Figure 6. Heteroscedasticity Test

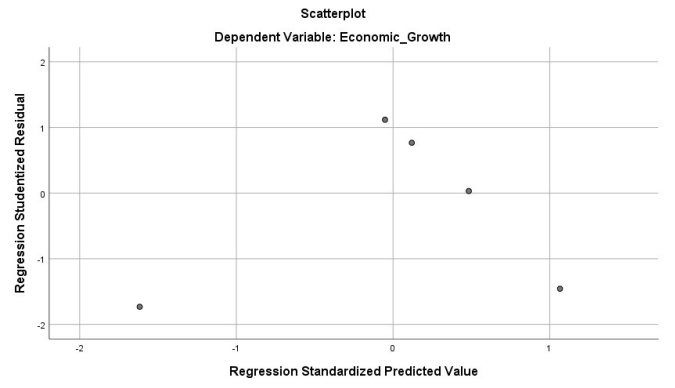

Source: Processed Data

\subsection{Multicollinearity Test}

Based on Table 1, the government bond variable VIF value is 3.907 . Because the VIF value is less than 10, government bonds do not experience multicollinearity symptoms. The VIF value of the inflation rate shows a result of 1.232. The VIF value is less than 10 so that the inflation rate also does not experience symptoms of multicollinearity. The last variable is the exchange rate which has a VIF value of 3.744. The VIF value is less than 10 so that the exchange rate does not experience multicollinearity symptoms.

Table 1. Multicollinearity Test 1

\begin{tabular}{|c|c|c|c|c|c|c|c|c|}
\hline \multicolumn{9}{|c|}{ Coefficients } \\
\hline & & \multicolumn{2}{|c|}{ Unstandardized Coefficientis } & \multirow{2}{*}{$\begin{array}{c}\text { Standarilizad } \\
\text { Coefficerts } \\
\text { Beta }\end{array}$} & \multirow[b]{2}{*}{1} & \multirow[b]{2}{*}{ Sig: } & \multicolumn{2}{|c|}{ Collinearity Statistitis } \\
\hline \multicolumn{2}{|l|}{ Model } & B & stol. Error & & & & Tolerances & UF \\
\hline \multirow[t]{4}{*}{1} & (Constant). & $-24,397$ & 2,644 & & $-9,226$ & 1069 & & \\
\hline & Govermert_Bond & $-1,033 E-14$ & 000 & $-1,228$ & $.34,465$ &, 018 & 250 & 3,907 \\
\hline & Intation & 20,821 & 585 &, 712 & 35,562 & 018 & 812 & 1,232 \\
\hline & Exchange_Rate &, 002 & .000 & .381 & 10,916 &, 058 & 267 & 3,744 \\
\hline
\end{tabular}

Source: Processed Data

Table 2 shows the VIF value of the economic growth variable of 1 . The VIF value is smaller than 10 so that the variable is free from multicollinearity symptoms.

Table 2. Multicollinearity Test 2

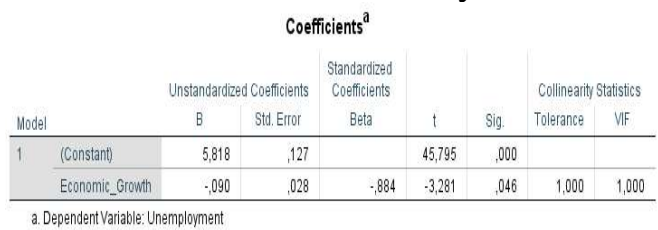

Source: Processed Data

Table 3 shows the VIF value of the variable economic growth rate of 1.000. This VIF value is less than 10 so that the economic growth rate against the poverty level does not experience multicollinearity symptoms. 
Table 3. Multicollinearity Test 3

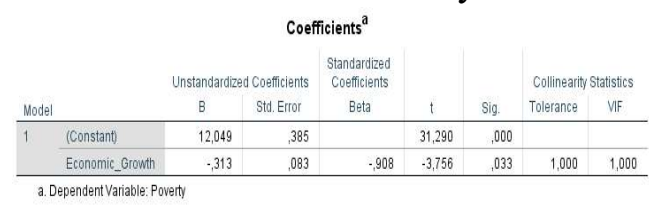

Source: Processed Data

\subsection{Descriptive Statistics}

Table 4. Descriptive Statistics

\begin{tabular}{|c|c|c|c|c|c|}
\hline \multicolumn{6}{|c|}{ Descriptive Statistics } \\
\hline & N & Minimum & Maximum & Mean & $\begin{array}{c}\text { Std. } \\
\text { Deviation }\end{array}$ \\
\hline Goverment_Bond & 5 & $2,40 E+14$ & $1,08 \mathrm{E}+15$ & $5,67 \mathrm{E}+14$ & $3,79 \mathrm{E}+14$ \\
\hline Inflation & 5 & .102025 & .378183 & .1889815 & .1089139 \\
\hline Exchange_Rate & 5 & 13329,83 & 14625,25 & 13950,23 & 565,3317 \\
\hline Economic_Growth & 5 & $-2,07$ & 5,17 & 3,6440 & 3,19477 \\
\hline Unemployment & 5 & 5,11 & 6,01 & 5,4610 & .35358 \\
\hline Poverty & 5 & 9,315 & 10,780 & 10,04000 & .566094 \\
\hline Valid N (listwise) & 5 & & & & \\
\hline
\end{tabular}

Source: Processed Data

Based on Table 4, it can be seen that government bonds have a minimum value of $2.4 \times 10^{14}$ with a maximum value of $1.08 \times 10^{15}$. The standard deviation of government bonds is $3.79 \times 10^{14}$. The inflation rate variable has a maximum value of 0.378 with a minimum value of 0.102 . The standard deviation for the inflation rate is 0.108 . The exchange rate variable has a minimum value of $\mathrm{Rp}$. 13,329 /US\$ with a maximum value of Rp. 14,625/US\$. The standard deviation for the exchange rate is IDR 565/US\$. Indonesia's economic growth rate over the past five years has also undergone various changes. The maximum economic growth rate is $5.17 \%$, with the lowest point of $-2.07 \%$ due to the covid19 pandemic. The standard deviation of Indonesia's economic growth is $3.19 \%$.

The unemployment rate increased relatively stable compared to other variables. This is evidenced by the standard deviation of the unemployment rate of only $0.35 \%$. The highest value of the unemployment rate is $6.01 \%$, with the lowest value of $5.11 \%$. The poverty rate has a standard deviation of $0.56 \%$. This causes the poverty rate in Indonesia not to change too much. The maximum value of the poverty rate is $10.78 \%$, with a minimum value of $9.31 \%$.

\subsection{Path Analysis}

The next test is path analysis. Path analysis will show the magnitude of the influence of the independent variable on the dependent variable. In path analysis, there are direct and indirect effects between the independent and dependent variables. Testing the effect of government bonds, inflation rates, and the rupiah exchange rate on Indonesia's economic growth are as follows.

Table 5. Regression Test 1

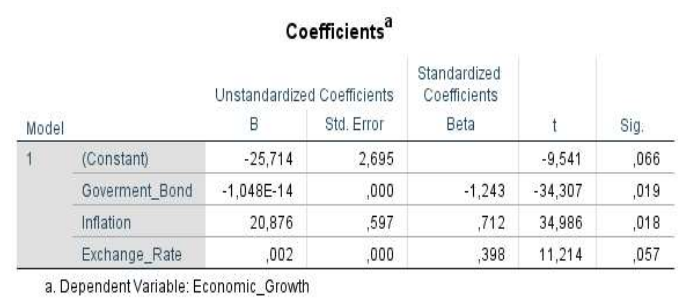

Source: Processed Data

Referring to table 5, government bonds have a significance value of 0.019 . This significance value is less than 0.05 so that government bonds have a significant effect on Indonesia's economic growth. This study is by the hypothesis $H_{1}$. These results are from research conducted by Sari, Hasanah, and Novalina (2020), where government bonds have a significant adverse effect on economic growth. This is an anomaly in government. Bonds issued by the government should increase the availability of funds for the government so that they can be used to increase the country's development. However, the opposite happened.

The issuance of government bonds has a negative effect on economic growth. This negative effect is caused by crowding out consumption. When 
domestic people buy government bonds, the availability of funds for consumption decreases. This reduction in consumption funds causes people's consumption power to decrease. The decrease in consumption power has the effect of decreasing consumption so that Indonesia's GDP also decreases. The effect of this decline in GDP will cause a contraction in economic growth. Based on this explanation, the issuance of bonds has a multiplier effect. The issuance of government bonds can increase government spending but, on the other hand, can reduce public consumption. With a decline in public consumption that is greater than the increase in government spending, Indonesia's GDP declines, causing a decline in the country's economic growth.

From table 5 above, the significance value of the inflation rate is 0.018 . This significant result has a value less than 0.05 so that the inflation rate has a significant effect on economic growth. The results of this study are in accordance with the $\mathrm{H}_{2}$ hypothesis. This is contrary to the research of Sari, Hasanah, and Novalina (2020), which states that the inflation rate has no significant effect on economic growth. The value of the standardized beta coefficient of 0.712 or $71.2 \%$ indicates that the inflation rate has a positive effect of $71.2 \%$ on economic growth. Phillips's theory suggests that inflation can reduce unemployment.

An increase in the inflation rate indicates that the prices of goods, in general, are increasing. This price increase is a stimulus for producers to produce more goods so that additional labour is needed. This will affect reducing unemployment. With more labour, the country's GDP will increase to its natural level in the long run. The increase in GDP will lead to an increase in economic growth. However, the inflation rate needs to be kept under government control because when the inflation rate is too high, it can cause crowding out of consumption and reduce economic growth.

The significance value of the rupiah exchange rate against the US dollar is 0.057 . The significance value is more significant than 0.05 . This shows that the rupiah's exchange rate against the US dollar has no significant effect on economic growth. This research is not in line with hypothesis $\mathrm{H}_{3}$. These results are also in line with research conducted by Setiawan and Mulyani (2020). This insignificance is because the exchange rate does not significantly affect Indonesia's exports and imports so that changes in GDP are not significant.

The exchange rate of the rupiah against the US dollar, which does not affect exports and imports, is because these goods are needed by both domestic and foreign people so that regardless of the exchange rate, the demand and supply of these goods will not change. This is further supported by the smoothness of international trade carried out by Indonesia so that there are no obstacles in carrying out exports and imports.

Table 6. Regression 2

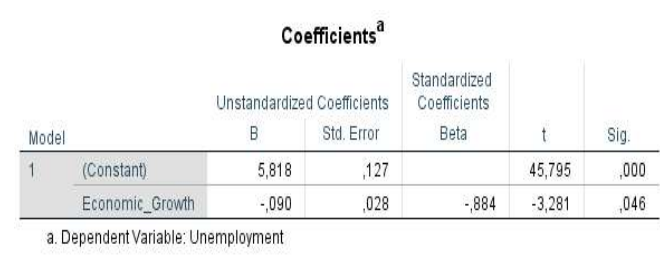

Source: Processed Data

Based on Table 6 above, the economic growth rate has a significance of 0.046 . The significance value is less than 0.05 so that the economic growth rate has a significant effect on the unemployment rate. The value of the standardized beta coefficient of -0.884 or $-88.4 \%$ indicates that the economic growth rate has a negative effect of $88.4 \%$ 
on the unemployment rate. This is by Okun's Law, which states that an increase in unemployment will cause a decrease in actual output, or a decrease in unemployment will increase real output. The results of this study are by the hypothesis $\mathrm{H}_{4}$.

Based on the GAP Model, the Okun Law applies throughout 2007-2015 in Indonesia. The research shows that the increase in output in the economy is due to the maximum absorption of labour and adequate employment opportunities. Both of these lead to a decrease in the unemployment rate. This was also proven when Indonesia experienced a crisis in 2008 where Indonesia's economic growth rate contracted deep enough to cause a recession. The recession caused many layoffs and a drastic reduction in job opportunities so that the unemployment rate increased significantly.

Table 7. Regression 3

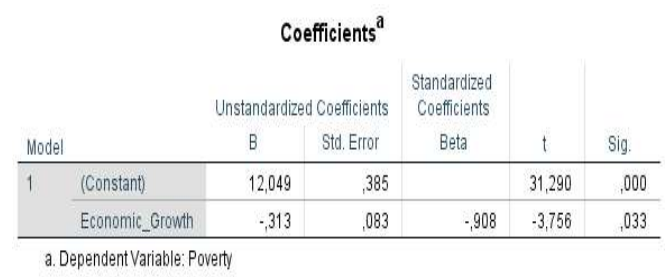

Source: Processed Data

In Table 7, the significance value of economic growth is 0.033 . The significance value is less than 0.05 so that the level of economic growth has a significant effect on the poverty rate in Indonesia. This is by hypothesis $\mathrm{H}_{5}$. The standardized value of the beta coefficient is -0.908 or $-90.8 \%$, indicating that the economic growth rate has a negative effect of $90.8 \%$ on the poverty rate. The higher the rate of economic growth, the lower the poverty rate. On the other hand, a decrease in the rate of economic growth causes an increase in poverty.

Seuss's research (2018) shows the same thing. Increasing GDP in agriculture, forestry, and industry can reduce poverty in Indonesia. The main thing that causes economic growth to reduce poverty is employment. The increase in GDP is due to the increase in the country's productivity in producing output. This increase will require additional workers. This need leads to an increase in employment, thereby reducing the level of poverty in Indonesia.

In determining the model's validity in path analysis, two indicators can be used. The first indicator is the coefficient of the total determinant. The coefficient of the total determinant is the total diversity of data explained by the model. The coefficient of the total determinant is measured by:

$\mathrm{R}^{2} \mathrm{~m}=1-\mathrm{P}^{2} \varepsilon_{1}-\mathrm{P}^{2} \varepsilon_{2}-\mathrm{P}^{2} \varepsilon_{3}$

$\mathrm{R}^{2} \mathrm{~m}=1-(0)^{2}-(0,467)^{2}-(0,418)^{2}$

$\mathrm{R}^{2} \mathrm{~m}=0,6072$

$\mathrm{R}^{2} \mathrm{~m}=60,72 \%$

The magnitude of $\mathrm{R}^{2} \mathrm{~m}$ is $60.72 \%$, meaning that the diversity of data that this research model can explain is $60.72 \%$, while the remaining $39.28 \%$ is explained by other variables that are not included in the research model.

\subsection{Trimming Method}

In determining the validity of the path analysis, the second method that can be used is the trimming method. The trimming method eliminates nonsignificant paths to obtain a model that is supported by empirical data. The research model after going through the trimming process is as follows. 
Figure 7. Trimming Method

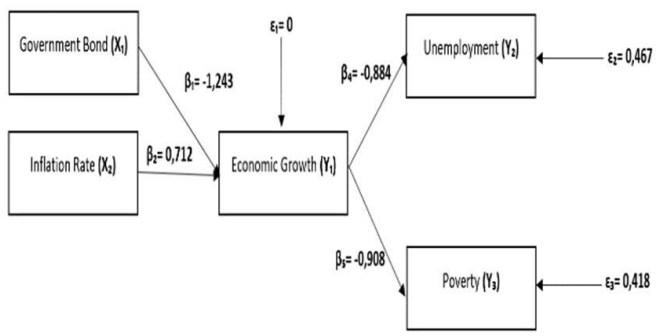

Source: Processed Data

The model above shows the indirect effect of government bonds $\left(\mathrm{X}_{1}\right)$ on the unemployment rate $\left(\mathrm{Y}_{2}\right)$ through the economic growth rate $(\mathrm{Y})$ of 1.098 or $109.8 \%$. This is by the hypothesis $\mathrm{H}_{6}$, which shows that government bonds are inversely proportional to economic growth so that it will increase the unemployment rate in Indonesia in line with the decline in economic growth. The opposite condition occurs if government bonds decline, then economic growth will increase. An increase in economic growth will lead to a decrease in the unemployment rate.

The inflation rate $\left(\mathrm{X}_{2}\right)$ shows an indirect effect on the unemployment rate $(\mathrm{Y})$ through the economic growth rate $(\mathrm{Y})$ of -0.6294 or $-62.94 \%$. This is by the hypothesis $\mathrm{H}_{7}$, which states that the inflation rate has an indirect effect on the unemployment rate negatively. This is by the Phillips theory, which states that there is a negative relationship between inflation and unemployment. As inflation increases, the prices of goods will increase. This condition is a stimulus for producers to produce more goods and services, thus requiring additional new workers. The increasing demand for labour causes the unemployment rate to decrease slowly. The opposite will happen when inflation is lowered to slow down, and the unemployment rate will rise.

Government bonds $\left(\mathrm{X}_{1}\right)$ indirectly affect the poverty rate $\left(\mathrm{Y}_{3}\right)$ of 1.128 or
$112.8 \%$. This is in accordance with hypothesis $\mathrm{H}_{9}$. An increase in government bonds will reduce economic growth, thereby increasing the poverty rate and vice versa. This can happen when too many government bonds are sourced from within the country, causing a crowding-out effect for public consumption. When public consumption weakens, Indonesia's GDP declines and lowers the rate of economic growth. As economic growth declines, unemployment increases according to Okun's Law. This increase in unemployment deepens the poverty gap in Indonesia.

The inflation rate $\left(\mathrm{X}_{2}\right)$ shows an indirect effect of -0.6464 or $-64.64 \%$ on the poverty rate in Indonesia (Y). This is by the hypothesis $\mathrm{H}_{10}$. An increase in the prices of goods is a stimulus for producers so that output increases. This increase in output will increase employment and GDP. According to the Phillips Theory, the increase in employment will reduce the unemployment rate, which leads to a decrease in the poverty rate in Indonesia.

The summary of direct and indirect effects between variables is as follows.

Table 8 . Summary

\begin{tabular}{|c|c|c|c|c|c|c|c|c|}
\hline & \multicolumn{2}{|c|}{$x_{1}$} & \multicolumn{2}{|c|}{$X_{2}$} & \multicolumn{2}{|c|}{$x_{3}$} & \multicolumn{2}{|c|}{$\gamma_{1}$} \\
\hline & $D$ & 1 & $D$ & 1 & $D$ & 1 & $D$ & 1 \\
\hline$Y_{1}$ & $-1,243$ & . & 0,712 & . & 0,398 & - & . & - \\
\hline$Y_{2}$ & . & 1,098 & . & $.0,6294$ & . & . & $.0,884$ & . \\
\hline$Y_{3}$ & . & 1,128 & . & $-0,6464$ & . & . & $-0,008$ & \\
\hline
\end{tabular}

Source: Processed Data

\section{CONCLUSION}

Based on the research above, the conclusions of this study are as follows.

1) Government bonds have a negative and significant effect on Indonesia's economic growth rate in 2016-2020. This means that when government bonds increase, there will be a 
decrease in the rate of economic growth.

2) The inflation rate has positively and significantly impacted Indonesia's economic growth rate in 2016-2020. This means that when the inflation rate increases, it will cause an increase in economic growth.

3) The rupiah's exchange rate against the US dollar has no significant effect on the level of economic growth in 2016-2020.

4) Economic growth has a negative and significant effect on the unemployment rate in 2016-2020. When there is an increase in the rate of economic growth, the unemployment rate will decrease.

5) Economic growth has a negative and significant effect on the poverty rate in 2016-2020. When there is an increase in the rate of economic growth, the poverty rate will decrease.

6) Government bonds positively and significantly indirectly affect Indonesia's unemployment rate in 2016-2020. This means that when government bonds increase, there will be an increase in the unemployment rate

7) The inflation rate has a negative and significant indirect effect on Indonesia's unemployment rate in 2016-2020. This means that when the inflation rate increases, there will be a decrease in the unemployment rate.

8) The rupiah exchange rate against the US dollar has no significant effect on the 2016-2020 unemployment rate.

9) Government bonds positively and significantly indirectly affect Indonesia's poverty level in 20162020. This means that when government bonds increase, there will be an increase in the poverty rate.
10) The inflation rate has a negative and significant indirect effect on Indonesia's poverty rate in 20162020. This means that when the inflation rate increases, there will be a decrease in the poverty rate.

11) The rupiah's exchange rate against the US dollar has no significant effect on the poverty rate in 20162020 . 


\section{REFERENCES}

Allam. (2020). Online Distance Learning Readiness During Covid-19 Outbreak Among Undergraduate Students. International Journal of Academic Research In Business And Social Sciences.

Ardiansyah, H. (2017). Pengaruh Inflasi Terhadap Pertumbuhan Ekonomi Di Indonesia. Jurnal Pendidikan Ekonomi (Jupe).

Basmar, E. (2020). Respon Fluktuasi Tingkat Upah Terhadap Perubahan Tingkat Pengangguran Di Indonesia. Jurnal Mirai Management.

Coibion, O. (2019). Monetary Policy Communications And Their Effects On Household Inflation Expectations. National Bureau Of Economic Research.

Costanza, R. (2014). Changes In The Global Value Of Ecosystem Services. Global Environmental Change. Elsevier.

Deonandan, R. (2019). Defining Poverty: A Summary Of Competing Models." Journal Of Social And Political Sciences. Journal Of Social And Political Sciences, 1721.

Engel, C. (2013). Exchange Rates And Interest Parity (No. W19336). National Bureau Of Economic Research.

Falk, G. (2021). Unemployment Rates During The Covid-19. Congressional Research Service.

Fetai, B. (2016). The Relationship Between Exchange Rate And Inflation: The Case Of Western Balkans Countries. Pressacademia.

Gatiningsih. (2017, Juli 11). Poverty Headcount Ratio At \$1.90 A Day (2011 Ppp) (\% Of Population). Diambil kembali dari Worldbank: Https://Data.Worldbank.Ord/Topic/11?End=2015\&Start=1990

Ginting, A. M. (2013). Pengaruh Nilai Tukar Terhadap Ekspor Indonesia. Buletin Ilmiah Litbang Perdagangan.

Goulden, C. (2014). A Definition Of Poverty. Jrf Programme Paper.

Gourinchas, P.-O. (2013). Capital Flows To Developing Countries: Capital Flows To Developing Countries. National Bureau Of Economic Research.

Haller, A.-P. (2012). Concepts Of Economic Growth And Development. Challenges Of Crisis And Of Knowledge. Economy Transdisciplinarity Cognition, 61-71.

Indiarti, M. (2018). Pengaruh Inflasi, Suku Bunga Bank Indonesia (Bi), Dan Nilai Tukar Rupiah/Us\$ Terhadap Perekonomian Indonesia. Jurnal Manajemen Kewirausahaan.

Khuhawar, K. H. (2019). Social Problems Due To Unemployment. Journal Of Marketing And Information Systems.

Li, Y. (2018). Structural Path Analysis Of India's Carbon Emissions Using Input-Output And Social Accounting Matrix Frameworks. Econ paper.

Mansi, E. (2020). Poverty-A Challenge For Economic Development? Evidence From Western Balkan Countries And The European Union. Sustainability.

Mpofu. (2020). Youth Unemployment: The Challenges And Possible Solutions For Zimbabwe's Lost Generation. Future Africa Forum.

Muhammad, U. F. (2019). Relationship Between Poverty And Unemployment In Niger State. Significant, 71-78. 
Nguyen, V. C. (2020). Impact Of Exchange Rate Shocks, Inward Fdi And Import On Export Performance: A Cointegration Analysis. Journal Of Asian Finance, Economics And Business, 163-171.

Perazzi, J. R. (2017). Analysis Of The Duration Of Unemployment And Outcomes For Unemployed Persons In The Bolivarian Republic Of Venezuela. Cepal Review.

Purnomo, S. D. (2019). Economic Growth And Poverty: The Mediating Effect Of Employment. Jejak: Journal Of Economics And Policy.

Rosa, Y. D. (2019). Pengaruh Inflasi, Kebijakan Moneter Dan Pengangguran Terhadap Perekonomian Indonesia. Jurnal Ekonomi Dan Bisnis Dharma Andalas.

Sama, Y. D. (2018). The Determinant Of Inflation In Indonesia: Partial Adjustment Model Approach. Jurnal Ekonomi \& Studi Pembangunan, 157-166.

Sari, W. I. (2020). Analisis Penerbitan Surat Utang Negara Terhadap Pertumbuhan Ekonomi Di Indonesia Melalui Inflasi Sebagai Variabel Mediasi Dalam Melawan Wabah Covid-19. Jurnal Kajian Ekonomi Dan Kebijakan Publik.

Sari, W. I. (2020). Analisis Penerbitan Surat Utang Negara Terhadap Pertumbuhan Ekonomi Di Indonesia Melalui Inflasi Sebagai Variabel Mediasi Dalam Melawan Wabah Covid-19. Jurnal Kajian Ekonomi Dan Kebijakan Publik.

Sari, W. I. (2020). Analisis Penerbitan Surat Utang Negara Terhadap Pertumbuhan Ekonomi Di Indonesia Melalui Inflasi Sebagai Variabel Mediasi Dalam Melawan Wabah Covid-19. Jurnal Kajian Ekonomi Dan Kebijakan Publik.

Sessu, A. (2018). Contribution Of Products Domestic Bruto (Gdp) Based On The Business Field On Poverty In Indonesia. World Journal Of Business And Management.

Swasono, D. A. (2015). Pengaruh Defisit Fiskal Terhadap Pertumbuhan Ekonomi Di Indonesia Periode 1990-2012. Jurnal Ekonomi Dan Pembangunan Indonesia, 144-157.

Wijaya, S. (2017). Analysis Of Factors Which Affecting The Economic Growth. Jurnal Ekonomi Dan Studi Pembangunan.

Yunita. (2018). The Influence Of Inflation Rate, Bi Rate, And Exchange Rate Changes To The Financial Sector Stock Price Index Return In The Indonesian Stock Market. Jurnal Manajemen Keuangan, 80-86. 